\title{
THE EFFECT OF PHYSICO-CHEMICAL PROPERTIES OF PROTEIN-DNA NANOPARTICLES ON THE TRASNFECTION EFFICIENCY OF CULTURED HELA AND MACROPHAGE CELLS
}

\author{
D. C. SILVA ${ }^{1}$, S. OTTENGY ${ }^{1}$, R. F. ALVES ${ }^{1}$, L. G. DE LA TORRE ${ }^{2}$, A. R. AZZONI ${ }^{1}$ \\ ${ }^{1}$ DEQ - Departamento de Engenharia Química, Escola Politécnica, USP \\ ${ }^{2}$ FEQ - Faculdade de Engenharia Química, UNICAMP \\ E-mail: danielcampossilva@hotmail.com
}

\begin{abstract}
A major concern in DNA vaccination and gene therapy protocols using non-viral vectors is the low efficiency of gene delivery. This is because during the traffic to the target cells nuclei, the DNA vectors must overcome a series of physical, diffusional and enzymatic barriers. The objective of this work is the development of novel delivery particles formed by the combination of proteins, plasmid DNA (pDNA), and lipids. We propose that these particles, also called "artificial viruses", will rely on the high efficiency of cell internalization of the lipids and then, exploit the cell machinery for intracellular trafficking to the interior of the cells nuclei. In this work, protamine-pDNA and protamine-pDNA-lipid nanoparticles were characterized by gel retardation assay, confirming the ability of the protamine to interact and condense pDNA. Zeta potential and dynamic light scattering studies indicated the presence of positive particles with size in the range of 100 to $700 \mathrm{~nm}$, depending on the incubation $\mathrm{pH}$ and time during nanoparticle formation. Transfection studies indicated that addition of protamine to pDNA (pVAX1GFP) and lipids increased the transfection efficiency of mammalian cells (HeLa), comparing to naked DNA. The next step of this study will be the transfection of macrophage cells IC21, hopefully achieving high transfection efficiencies, and adding new information on how the physico-chemical properties of the nanoparticles correlate with transfection efficiency of mammalian cells.
\end{abstract}

\section{INTRODUCTION}

One of the major challenges on the development of efficient protocols for gene therapy and DNA vaccination is the low efficiency of gene transfer by non viral vectors. This is mainly attributed to the fact that, during the traffic to target cells nuclei, plasmid vectors must overcome a series of physical, enzymatic and diffusional barriers (Edelstein, 2007). There are several requirements for an efficient delivery vector: (1) condensation of the nucleic acid and protection from exogenous endonucleases, (2) stability of the delivery complex in the blood or extracellular environment, (3) enhanced uptake by the target cells, (4) escape from endosomal entrapment, (5) protection from cytoplasmic nucleases, (6) enhanced DNA transport towards the nucleus and, (7) facilitation of nuclear membrane transposition (Guo and Huang 2012). Usually, viral vectors are naturally capable of efficiently performing all of these tasks but have the limitations of safety concerns, such as adverse 


\section{9 a 22 de outubro de 2014 \\ Florianópolis/SC}

side effects and the generation of immune responses [3]. Therefore, there has been a continuous effort to study and develop non viral vectors with an enhanced efficiency, comparable to that of the viralbased vectors. So far, several different non viral gene delivery vectors based on cationic lipids, cationic polyplexes, peptides and metal nanoparticles have been reported (Amand et al. 2012; Zhang et al. 2008; Morishita et al. 2005; Parker et al. 2003).

The objective of this work was the development and characterization of new multifunctional non-viral vectors, based on lipids and protein, able to delivery efficiently the foreign pDNA (plasmid DNA) to the nucleus of mammalian cells. A model pDNA containing the reporter gene GFP was complexed to protamine, forming "binary complexes" (BC). In addition, we studied the ability of the cationic liposomes (EPC:DOPE:DOTAP) to encapsulate this binary complexes to form "pseudoternary complexes" (PTCs). In the near future, we hope to add new information on how $\mathrm{pH}$ and ionic strength used during complexation can affect the properties, stability and transfection efficiency of theses vectors. In especial, we hope to use these information in order to better control the physicochemical properties of the vectors in order to efficiently transfect macrophage cells.

\section{METHODOLOGY}

\section{Plasmid DNA vector}

The plasmid DNA used in this study, pVAX1GFP, was previously described by Azzoni et al. (2007). Purification of the pVAX1GFP plasmid used in all studies was performed as described by Favaro et al. (2012).

\section{Preparation of the cationic liposome}

Cationic liposomes were prepared by thin film method as described by Balbino et al. (2012). Briefly, a mixture of Egg phosphatidylcholine (EPC), 1,2-dioleoyl-sn-glycero-3phosphoethanolamine (DOPE) and 1,2-dioleoyl-3-trimethylammonium-propane (DOTAP) (50/25/25\% molar) were solubilized in chloroform and subsequently the solvent was removed in a rotary evaporator under vacuum of $650 \mathrm{mmHg}$ for $1 \mathrm{~h}$. The dried lipid film was hydrated with PBS buffer to a lipid final concentration of $16 \mathrm{mM}$. The hydrated liposomes were extruded through double polycarbonate membranes (100 nm nominal diameter) 15 times under nitrogen $\left(12 \mathrm{kgf} / \mathrm{cm}^{2}\right)$.

\section{Evaluation of pDNA-protein interaction by gel retardation assay}

The ability of protamine or lipids to interact and condense pDNA was evaluated by gel retardation assay. Protamine sulfate powder (Sigma-aldrich, USA) was resuspended in PBS buffer and incubated with $1 \mu \mathrm{g}$ of pVAX1GFP vector (previously in PBS buffer) at various pDNA:protein mass ratios $(1: 0.5,1: 0.7,1: 0.9,1: 1,1: 2$ and 1:5) in a final volume of $50 \mu \mathrm{L}$. The samples were incubated at room temperature for $20 \mathrm{~min}$. Samples were run on a $0.8 \%$ agarose gel and visualized by ethidium bromide staining. The pDNA:protamine:liposome (pseudo-ternary complexes) complexes were obtained by adding $15 \mu \mathrm{l}$ of liposome at a concentration of $2.4 \mathrm{mM}$ to the pDNA:protamine complexes (for all pDNA:protamine mass ratios), followed by vortex for 40s and incubation at ice bath for $10 \mathrm{~min}$. After second vortexing step, the liposomes were let stand at room temperature for 30 


\section{9 a 22 de outubro de 2014 \\ Florianópolis/SC}

$\min$.

\section{Zeta potential and dynamic light scattering assays}

Zeta potential measurements were performed to comparatively evaluate the surface charge of complexes formed by pDNA:protamine (binary complexes - BC) or pDNA:protamine:lipossome (pseudo-ternary complexes - PTC) at different mass ratios. The measurements were taken by applying an electric field across the samples, and the value of the zeta potential was obtained by measuring the velocity of the electrophoretic mobility of the particles using the laser Doppler anemometry technique. Complexes were formed as previously described for the gel retardation assay. Each sample was measured six times using the Malvern Zetasizer Nano ZS (Malvern). The assays were performed in triplicate. The average hydrodynamic diameter and size distribution (number-weighted) of the complexes were measured via the dynamic light scattering (DLS) technique using a Malvern Zetasizer Nano ZS with a backscattering configuration and detection at a scattering angle of $173^{\circ}$, using a $\mathrm{He} / \mathrm{Ne}$ laser emitting at $633 \mathrm{~nm}$ and a $4.0 \mathrm{~mW}$ power source. The pDNA:protamine complexes were measured at several different mass ratios. Complexes were formed with $1 \mu \mathrm{g}$ of pDNA and the corresponding amount of protein (and lipossome) in a final volume of $800 \mu \mathrm{L}$. Each sample was subjected to multiple readings in a 60 -min period.

\section{Culture and transfection of HeLa cells}

HeLa cells were grown in a F-12 (Ham) nutrient mixture (Gibco) containing 10\% (v/v) fetal bovine serum (growth medium, Gibco). The cells were cultured in $75 \mathrm{~cm} 2$ culture flasks and incubated in a $5 \% \mathrm{CO}_{2}$ humidified environment at $37^{\circ} \mathrm{C}$. Following growth to confluence, cells were trypsinized and seeded in 24-well culture plates (5 x 104 cells per well). The cells were incubated for 48 hours (to $70 \%$ confluence) and then transfected with pDNA:protein or pDNA:protamine:lipossome complexes formed as described previously for gel retardation assays, using the same molar ratios. When indicated, transfection was carried out using the Lipofectamine 2000TM reagent (Invitrogen) according to the manufacturer's instructions $(1 \mu \mathrm{g}$ pDNA plus $1.5 \mu \mathrm{L}$ reagent in $100 \mu \mathrm{L}$ of medium per well). All transfections were carried out in the presence of serum. The medium containing the transfection solution remained on the transfected cells for 6 hours and was then replaced with fresh growth medium. Cells were collected 24 hours post-transfection and the number of cells expressing the reporter gene GFP was determined by flow cytometry, as described previously by Azzoni et al. (2007).

\section{RESULTS}

An important feature of gene delivery vectors is the ability to condense and protect nucleic acids, avoiding degradation by shear forces or nucleases during extra and intra-cellular trafficking. As seen in Figure 1, protamine peptide has the ability to efficiently condense plasmid DNA (pDNA) even at low mass ratious (1:1 and above). We also verified by gel retardation assay that, at all mass ratios used, the binary complexes (BCs) formed by pDNA:protamine could be efficiently encapsulated by the lipossomes, forming pseudo-ternary complexes (PTCs) that were 
anable to migrate in the agarose gel (data not shown).

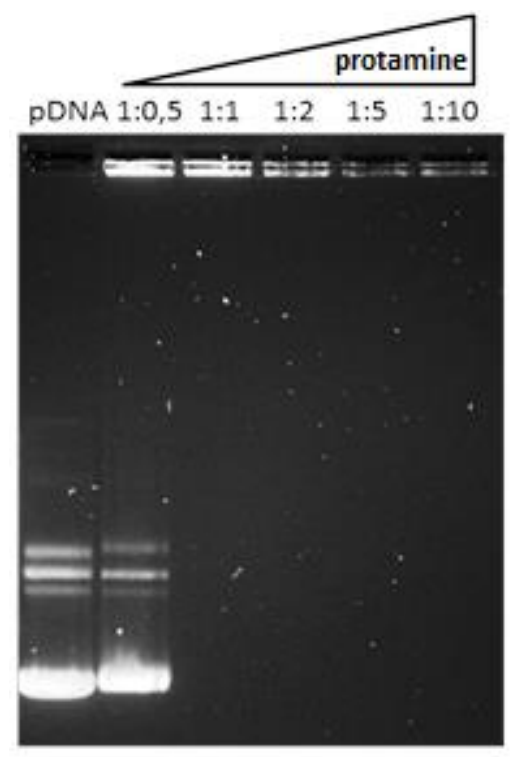

Figure 1 - Gel retardation assay for the analysis of the interaction between protamine and pDNA (agarose gel at 0.8\%). Several plasmid DNA:protamine mass ratios were studied (0, 1:0.5, $1: 1,1: 2,1: 5$ and $1: 10$ ) as shown in the figure legend.

Another important physico-chemical characteristics of a vector for gene delivery are size and charge. Figure 2A shows the values obtained for particle size of CBs obtained at different mass ratios and $\mathrm{pH}$ values during complexation. It was also possible to verify that, besides particle sizes, the values found for polydispersity were lower for $\mathrm{pH} 6$ than for $\mathrm{pH} 8$ (data not shown). These results indicate that both, size and polidispersity could be at some level controled by the $\mathrm{pH}$ of complexation. This find could be used for the preparation of complexes tailored for a especific type of target cell. Per example, macrophages tends to be better transfected using transfecting particles with sizes greater than $500 \mathrm{~nm}$, while most of the cells are better transfected using particles smaller than $200 \mathrm{~nm}$, due the endocytosis mechanism of pDNA uptake.

The DLS results obtained for the pseudo-ternary complexes (Table I) indicated small particle sizes at all pDNA:protamine ratios used. This result indicated that encapsulation by the liposome was efficient at the presence of the protamine, despite polydispersity was higher at BC mass ratios close to $1: 1$, probably as a result of the low zeta potential of these particles. The zeta potential of a DNA vector is very important for its delivery efficiency. As a coloidal system, values of zeta potential close to zero tend to lead the particles to agregate and precipitate. Gene delivery vectors frequently have positive zeta potential, necessary for charge interaction with cells membranes that will ultimately lead to cell uptake, generaly by endocitosys. Figure 2B presents the zeta potential values found for the binary complexes (pDNA:protamine) at several mass ratios. Differently from the binary complexes, all pseudo-ternary complexes presented 
positive zeta potential (between +23 and $+35 \mathrm{mV}$ ), despite the pDNA:protamine used (results not shown). This result also indicate that encapsulation by the liposome is efficient at the presence of the protamine.
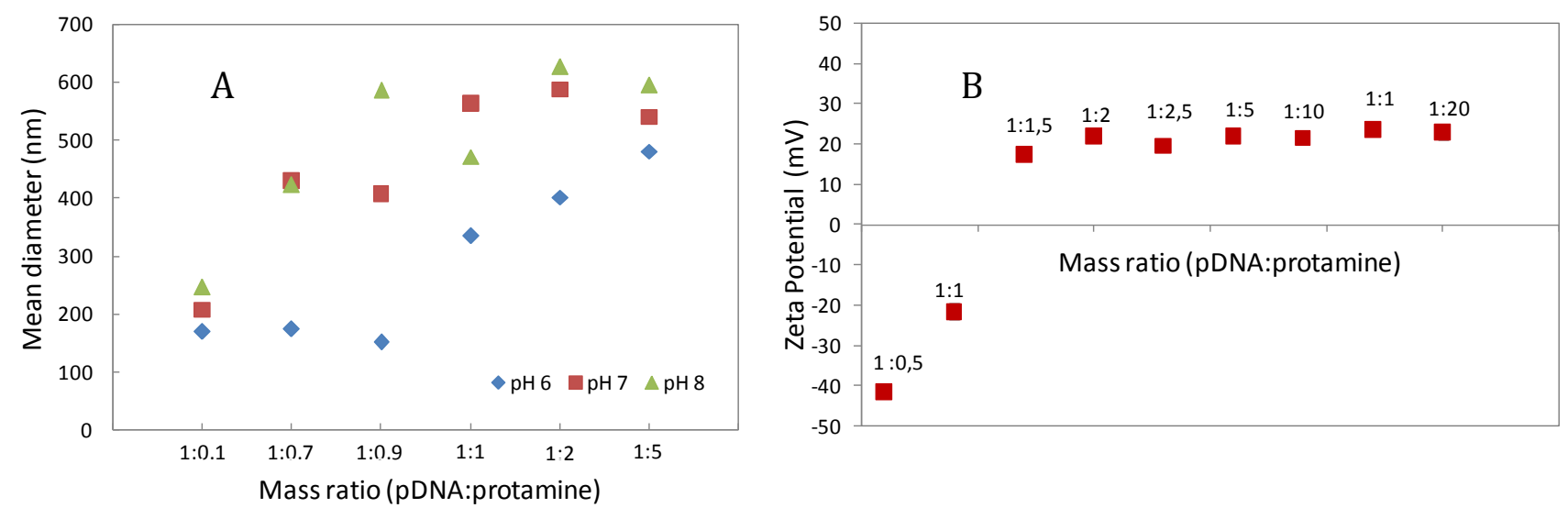

Figure 2 - Dynamic light scattering (A) for the measurement of particle size (in number) formed at different pHs (PBS buffer at $\mathrm{pH} \mathrm{6,7}$ and 8); and zeta potential analysis (B) of BCs formed at $\mathrm{pH}$ 7. Several pDNA:protamine mass ratios were studied as shown in the legends.

Table I - Size and polydispersity of the pseudo-ternary complexes formed using different pDNA:protamine $(\mathrm{CB})$ mass ratios.

\begin{tabular}{ccc}
\hline CB mass ratio & $\begin{array}{c}\text { Mean diameter in } \\
\text { number (nm) }\end{array}$ & $\begin{array}{c}\text { Polydispersity } \\
\text { (PDI) }\end{array}$ \\
\hline $1: 0.5$ & $123.1 \pm 2.3$ & $0.310 \pm 0.015$ \\
\hline $1: 0.7$ & $101.9 \pm 0.9$ & $0.588 \pm 0.066$ \\
\hline $1: 0.9$ & $108.6 \pm 3.9$ & $0.662 \pm 0.061$ \\
\hline $1: 1$ & $106.0 \pm 3.9$ & $0.566 \pm 0.162$ \\
\hline $1: 1.5$ & $110.4 \pm 0.9$ & $0.379 \pm 0.050$ \\
\hline Empty lipossome & $96.4 \pm 0.4$ & $0.115 \pm 0.011$ \\
\hline
\end{tabular}

Finally, we have evaluated the efficiency of the binary and pseudo-ternary complexes to 
transfect HeLa cells in vitro. Despite some efficiency of the binary complexes could be noted, better results were found when the pDNA:protamine particles were encapsulated in liposomes, forming the pseudo-ternary particles. A synergic effect of the protamine and the lipids could be observed, since the transfection efficiencies of the particles containing protamine were always higher than the pDNA:liposome particle.

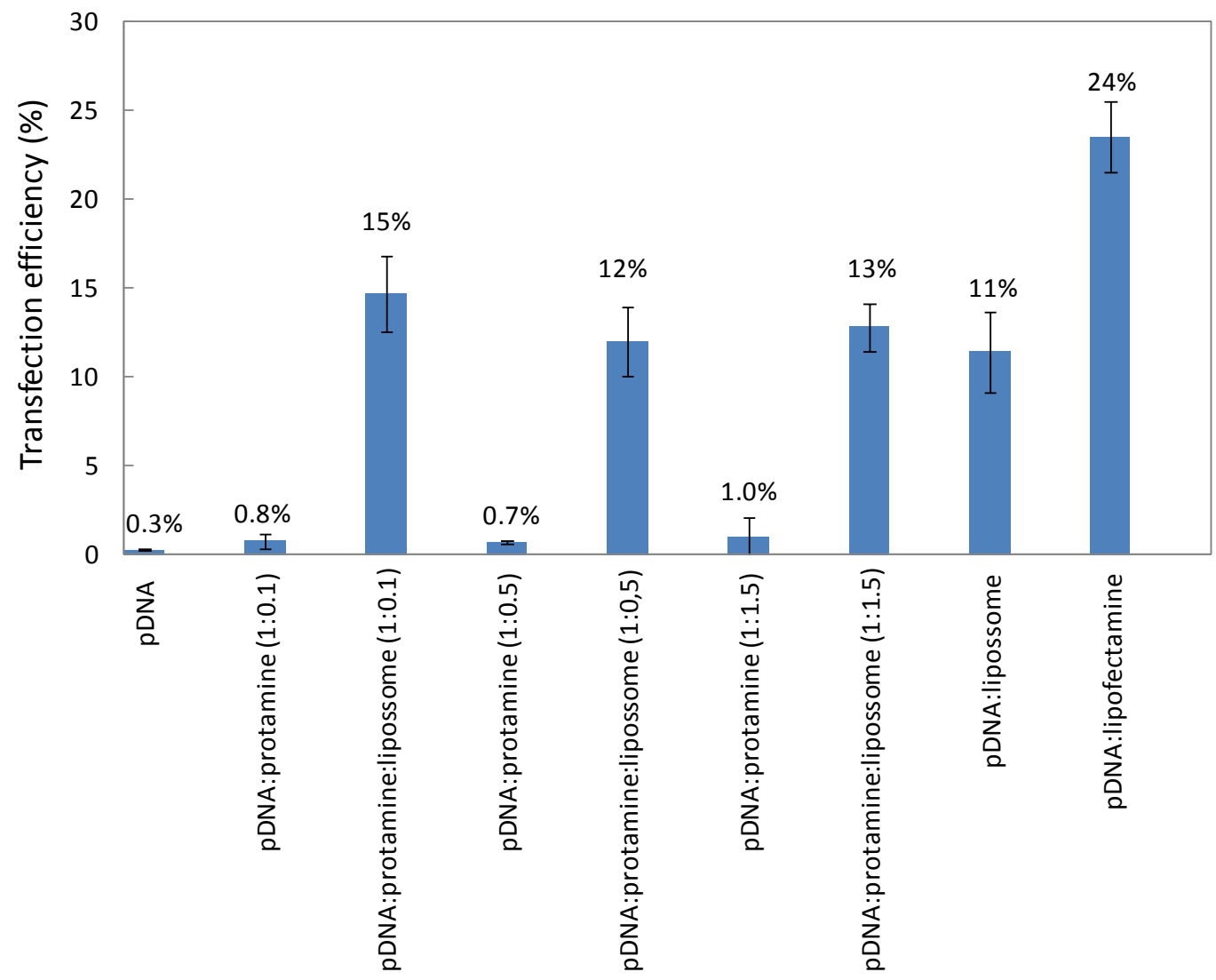

Figure 3 - Transfection efficiency of HeLa cells comparing naked pDNA, pDNA:protamine (BC) at different mass ratios, pDNA:protamine:liposome complexes at different BC mass ratios, and Lipofectamine $2000^{\mathrm{TM}}$. Transfection efficiency was assessed by measuring the expression of the green fluorescent protein reporter gene of the pVAX1GFP plasmid. Error bars indicate the standard deviation of triplicates.

\section{CONCLUSION}

The results presented here indicated that protamine is efficient to condense pDNA, but could not transfect efficiently the culture HeLa cells, at least using the condions described here. 
By adding the liposome to the formation of CPTs, higher values of in vitro transfections could be obtained, for all ratios of pDNA:protamine studied, indicating that protamine plays a role during the intracellular trafficking of the pDNA particle. Possible explanations are increased protection of pDNA from nuclease degradation, and increased efficiency of nuclear translocation, due to the protamine nuclear localization signal. Finally, the results obtained so far points to the possibility of using the $\mathrm{pH}$ of complex formation to modulate the complex particle size and, possibly increase the efficiency of this non viral vector to transfect macrophages, that is the major goal of this work.

\section{REFERENCES}

AMAND, HL.; NORDEN, B .; FANT, K. Functionalization with C-terminal cysteine enhances transfection efficiency of cell-penetrating peptides through dimer formation. BiochemBiophys Res Commun. 418:469-474, 2012.

AZZONI, A.R.; RIBEIRO, S.C.; MONTEIRO, G.A.; PRAZERES, D.M. The impact of polyadenylation signals on plasmid nuclease-resistance and transgene expression. J Gene Med. V.9, N 5, p.392-402, 2007.

BLABINO, T.A.; GASPERINI, A.A.M. ; OLIVEIRA, C.L.P. ; AZZONI, A.R. ; CAVALCANTI, L.P. ; TORRE, L.G.L. Correlation of the physico-chemical and structural properties of pDNA/Cationic liposome complexes with their. Langmuir. v.28, p. 11535-11545, 2012.

EDELSTEIN, M.L.; ABEDI, M.R.; WIXON, J. Gene Therapy Clinical Trials worldwide to an update. J Gene Med. V.9, N¹0, p.833-842, 2007.

FAVARO, M.T.P. Desenvolvimento de vetores não virais para entrega gênica baseados na cadeia leve da dineína RP3. Tese de Mestrado. Universidade Estadual de Campinas, São Paulo, 2012.

GUO, X ; HUANG, L. Recent advances in nonviral vectors for gene delivery. AccChem Res. 45 971-979, 2012.

MORISHITA, N.; NAKAGAMI, H.; MORISHITA, R.; TAKEDA, S.; MISHIMA, F.; TERAZONO, B.; NISHIJIMA, S.; KANEDA, Y.; TANAKA, N. Magnetic nanoparticles with surface modification enhanced gene delivery of HVJ-E vector. BiochemBiophys Res Commun. 334:1121-1126, 2005.

PARKER, AL.; NEWMAN, C.; BRIGGS, S.; SEYMOUR, L.; SHERIDAN, PJ. Nonviral gene delivery: techniques and implications for molecular medicine. Expert Rev Mol Med. 5:201-215, 2003. 
ZHANG, Z.; SHA, X.; SHEN, A.; WANG, Y.; SUN, Z.; GU, Z .; FANG, X. Polycation nanostructured lipid carrier, a novel nonviral vector constructed with triolein for efficient gene delivery. BiochemBiophys Res Commun. 370:478-482, 2008.

\section{AKNOWLEDGMENTS}

The authors would like to thank FAPESP, CAPES and CNPq for the financial support. 